\title{
A Pragmatic Analysis of Some Quranic Verses in Light of Grice's Cooperative Principle
}

\author{
Suhayla H. Majeed ${ }^{1}$, Ismail A. Abdulla ${ }^{2}$ \\ ${ }^{1}$ Department of English, College of Languages, Salahaddin University-Hawler, Erbil, Kurdistan Region, Iraq \\ ${ }^{2}$ Department of Translation Techniques, Erbil Administrative Technical Institute, Erbil Polytechnic University, Erbil, \\ Kurdistan Region, Iraq
}

\begin{abstract}
The present paper is an attempt to evaluate the applicability of Grice's Co-operative Principle and Conversational Maxims, as one of the outstanding models in Pragmatics, to some selected Quranic conversations. Grice's model is regarded as template for the flow of conversations and interactions held between people. Quran, as a Holy Text in Islam, contains many speech events, i.e., situations wherein conversations take place. In the stories narrated in Quran, there are situations in which, as the ordinary life of the human beings, participants converse with one another. In this study, the researchers examine the applicability of the conversation model of Grice to the Quranic conversations. To this end, the researchers have quoted some verses from Quran, first in Arabic along with their translations in English, and analysed them in light of Grice's model of conversation analysis. Findings indicate that in the Quranic conversations there are occasions where the maxims of conversation are observed and in some other cases not observed. This fact attests the universality of Grice's model.
\end{abstract}

Index Terms - Pragmatic Analysis, Cooperative Principle, Conversational Maxims, Quranic Verses.

\section{INTRODUCTION: GRICE'S THEORY OF}

The key ideas of this theory were proposed by Paul Grice(19131988), the father of Pragmatics, in the William Games lectures delivered at Harvard University in 1967 and later partially published in Grice's "Logic and Conversation" (1975). The proposals were relatively brief and only suggestive of how future work might be proceeded. The theory of implicature is about how people use language. Grice suggested that there is a set of over-arching assumptions guiding the conduct of conversations. These assumptions arise from basic rational considerations and may be formulated as guidelines. Grice identifies four basic maxims of conversation or general principles underlying the efficient cooperative uses of language which jointly express a general Cooperative Principle (CP).

The CP says 'Make your conversational contribution such as is required, at the stage at which it occurs, by the accepted purpose or direction of the talk exchange in which you are engaged' (Grice, 1975, p. 45). In order to have a smooth flow of a conversation the participants have to be co-operative in the process of their interaction with each other. Grice (1975), in an attempt to provide a more complete explanation of his CP he suggested a four-folded theory of conversations called Conversation Maxims (CMs). Some of the maxims have further submaxims. The maxims and their submaxims are as follows:

1. Maxim of Quality: Try to make your contribution one that is true, specially:

a) Do not say what you believe to be false.

b) Do not say that for which you lack adequate evidence.

2. Maxim of Quantity

a) Make your contribution as informative as required for the current purposes the exchange.

b) Do not make your contribution more informative than is required.

3. Maxim of Relevance: Make your contributions relevant

4. Maxim of Manner: Be perspicuous and specially:
a) Avoid obscurity
b) Avoid Ambiguity
c) Be brief i
d) Be orderly (see Grice, 1975, pp. 45-6)

To sum up, these maxims specify what the participants have to do in order to converse in maximally efficient, rationally cooperative way. They should speak: sincerely, relatively, and clearly, while providing sufficient information.

A question rises. Do conversers abide by the co-operatives principle? Or do they violate these maxims? Simply, "NO!" will be the answer. So what should the participants do then? They do not observe the maxims. When the participants do not abide by these maxims, how can they get along with the flow of the conversation then? The answer is that there is an implicated meaning by which the hearers infer the intended meaning. This implicated meaning is known as implicature. There are two

Journal of University of Human Development

Volume 5 No. 3(2019); DOI: 10.21928/juhd.v5n3y2019.pp127-133

Regular research paper: Published 29 July 2019

Corresponding author's e-mail: perdawdy84@gmail.com, esmael.abdulla@epu.edu.iq

Copyright (C) 2019 Suhayla H. Majeed, Ismail A. Abdulla. This is an open access article distributed under the Creative Commons Attribution

License (CC BY-NC-ND 4.0) 
ways via which implicatures are obtained: observing, i.e., abiding by the maxims fully, and by not observing the maxims. When not observing the maxims, only flouting generates implicature, as we will see at the end of this section. First, we look at some examples of implicatures by observing the maxims:

(1) John has two houses.

$+>$ I believe he has, and have adequate evidence that he has.ii

(2) Does your farm contain 400 acres?

$+>$ I don't know that it does, and want to know if it does.

(3) Helen has fourteen children. $+>$ only fourteen

(4) The flag is white. $+>$ only white.

(5) Pass the salt. $+>$ Pass the salt now.

(6) A: Can you tell the time?

B: The newspaper boy has come.

$+>$ I don't know exactly but it has passed the usual time at which the newspaper boy comes, say, 7:30, for example.

(7) Open the door. +> walk up to the door, turn the door handle clockwise as far as it will go, then pull gently towards you.

(8) I went to the library and borrowed a book. $+>$ I firstly went to the library and secondly borrowed a book. (Adapted from Levinson, 1983, pp. 105-7)

To observe the maxim of quality leads to the implicature in (1) and (2). The maxim of quantity causes the implicatures in (3) and (4). Considering the maxim of relevance in (5) and (6 B)results in the implicatures there. The implicature in (7) is due to observing the submaxim of manner 'be brief' and the one in

(8) is by observing the submaxim of manner, 'be orderly.'

Not observing the maxims may take one of the following shapes:

1. Violating a maxim: Violating a maxim is to fail to observe it, but to do so inconspicuously (unnoticeably) with the assumption that the hearer will not realize the maxim is being violated. A typical example is to tell a lie. The speakers here intend to mislead (deceive) the addressees by telling lies or hiding the truth totally or partially. Examples will be quoted from Quranic verses when applying the model.

2. Infringing a maxim: Infringing a maxim is when a speaker, who, with no intention of generating an implicature with no intention of deceiving, fails to observe a maxim is said to 'infringe' the maxim. In other words the implicature here is generated from imperfect linguistic performance rather than from any desire on the part of the speaker. Such non-observance of the maxims will happen in speakers with imperfect command of language. It may occur in young children, or foreign learners due to nervousness, drunkenness, excitement etc. they may be incapable to speak clearly, as in the following example, A is an English speaker, while B is not:

(9) A: Would you like to have a cheeseburger or hamburger, Sir?

B: Yes. (Younis, 2015, p. 16)

As Younis (2015, p. 16) explains B's reply is to be regarded as no-co-operative because B has not understood A's intention. Therefore, it does not even generate an implicature!

3. Opting out a maxim:A speaker opts out of (i.e., refuses) observing a maxim by unwillingness to co-operate in the way the maxim requires. Examples of opting out occur frequently in public life, especially for politicians, police investigation cases and affairs related to legal reasons. Opting out may be chosen for the purpose of not hurting the third party, as in (14) and

(10) A: What was this meeting about?

B: Well, honestly, I can't tell you a thing, because what said to me was told me in confidence.

4. Suspending a maxim: Speakers sometimes suspend the maxims when they do not know the exact information or when they are not ready to communicate. This type of nonobservance is culture-dependent. An example maxim of quantity suspensions will be found in telegrams, teletext $[\mathrm{t}] \mathrm{s}$ and some international phone calls (Thomas, 1995, pp. 7678)

In some Kurdish communities, for instance they may not mention the name of a dead person, instead they say "rahmati" (=the late) which is again suspending the maxim of manner, be clear.

5. A clash, as Black (2006, pp. 24-5) argues, is another way of not observing the maxims. A clash occurs when one cannot be fully co-operative. For example, to satisfy one maxim (say, of quantity) might require one to ignore or break another (of quality). An indicator for this way of not observing the maxims fully is the use of hedges, as I understand that, to the best of my knowledge, it seems to $m e$, etc. (See Black 2006, pp. 24-5 and Yule 1996, pp. 389).

6. Flouting a maxim is when blatantly (deliberately) you fail to observe a maxim. So this deliberate non-observance of the maxim of quality generates an implicature, as in(11) (Adapted from Levinson, 1983, p. 109):

(11) A: What if Iran blockades the Persian Gulf and all the oil?

B: Oh come now, Iraq rules the seas.

+> the opposite is true, or Iraq does not rule the seas, Iraq can do nothing.

The tautologies in(12) B and(13) B flout the maxim of quantity

(12) A: I am very sorry about the consequences, you see.

\section{B: War is war.}

+> you have to expect terrible things happen in wars and there no need to be sorry about.

(13) A: I lost a lot last year.

B: Business is business.

$+>$ you have to expect to lose when doing business.

(14) A: Let's get the kid's something

B: O.K., but I veto S-W-E-E-T-S.

+> I don't like you to buy sweets and even don't mention it.

In (14) B, the maxim of manner is violated. B does not want to mention sweets, thus B spells it, in order not that the kids are prompted with it lest they eventually demand some. In the coming sections further examples from the verse of the Quran will be provided. 


\section{QURAN AS A TEXT: A SHORT OVERVIEW OF QURAN}

Quran, also spelled as Koran, or as القرآن Qur'an in Arabic, here Quran is preferred, is regarded, a long side with the hadiths, the Prophet Muhammad's sayings (peace be upon him), as the Holiest in Islam. To have the belief that Quran is from Allah , sent down to His slave and prophet, Muhammad, is one of the Islamic basic doctrines. Thus all the followers of Islam, i.e., Muslims, believe that Quran is the absolute truth and whatever is mentioned there is accordingly true. Linguistically speaking, Quran is regarded as the word of Allah, and the text is regarded as the sacred bedrock of Islam.

Quran was revealed and sent down orally to the prophet Muhammad (peace be upon him) in Arabic language over 23 years, beginning from 610 AD (Stranzy, 2005, p. 75). Quran was first documented and scripted during the prophet's era but collected in one volume after his death (peace be upon him). Stranzy (2005, p. 75), in the Encyclopedia of linguistics, states that "the language of the Qur' an is commonly held by Muslims to be that of God. [...] All Muslims are expected to recite scripture and pray in Arabic even if they do not understand what they are saying or reading."

Quran has been divided into 30 parts. These 30 parts are also subdivided into further chapters called Suras. There are 114 Suras. Each Sura consists of a different number of verses with various lengths. The total number of the Quranic verses is 6236 (Appendix of Al-Quran Al-Kareem, 2014, pp. 607ff).

\section{PREVIOUS STUDIES}

Because of including many conversations, so many researchers who are interested to find out about the conversation structure and linguistic functions of Quran conducted pragmatic studies. Here, we refer to only two of which pertained to the topic of the present study, Grice's theory of conversation.

Badejani et al. (2013) carried out a text analysis of AlAn'am (The Cattle) Sura according to the Gricean theory of implicature. They merely concentrated on the violation of the maxims. The research found out that there are all the cases where the maxims are neglected but their frequency varies from place to place in the Sura of Al-An'am only.

In Mahfouz (2013), though the current researchers have only accessed to the abstract of the study, it seems from the title that Mahfouz conducted a vast study of the Quranic dialogues in the light of the pragmatic theories. One chapter of the study is provided only for the study of the analysis of the dialogues of Quran in the framework of Grice's co-operative principle. It was concluded that implicature plays an important role in providing better understanding of the Quranic verses.

\section{Data Collection and METHODOlOGY}

The present study is a trial to provide thorough analyses to some selected Quranic conversations adopting the $\mathrm{CP}$ and $\mathrm{CMs}$ proposed by Grice. It seeks to supply ample examples about the hypothesis claiming the universality of the theories. The researchers have quoted some Quranic conversations to check to what extent the $\mathrm{CP}$ and $\mathrm{CMs}$ are observed or ignored. All the quotes will be first in Arabic language and below each example the English translation is provided from Saheeh International
(2004). So, the present study is a qualtitative analysis of some Quranic conversations in the light of Grice's CP and CMs.

\section{DISCUSSIONS AND FINDINGS}

As we mentioned earlier dialogues and conversations pervade the Quranic text. In this section we will first look at those conversations in which the $\mathrm{CP}$ and $\mathrm{CMs}$ of Grice are met. Coincidently, reference will be made to those conversations that ignore the $\mathrm{CP}$ and $\mathrm{CMs}$.

\section{A. MAXIM OF QUALITY}

In the following verse, the conversation abides by the maxim of quality:

(15) (The bold is our emphasis in all of the examples)

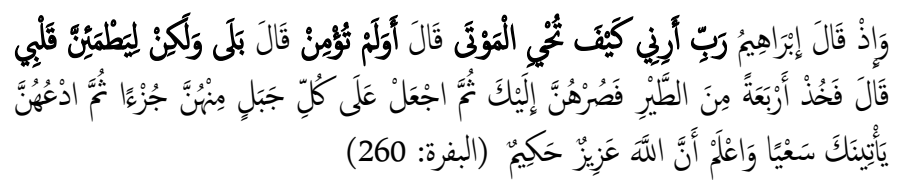

And [mention] when Abraham said, "My Lord, show me how You give life to the dead." [Allah] said, "Have you not believed?" He said, "Yes, but [I ask] only that my heart maybe satisfied." [Allah] said, "Take four birds and commit them to yourself. Then [after slaughtering them] put on each hill a portion of them; then call them - they will come [flying] to you in haste. And know that Allah is Exalted in Might and Wise." (Saheeh International, 2004, p. 39)

In (15) Abraham expresses himself as having belief in Allah, when Allah asked him whether he has not believed in Him, then he replies with what he has in himself and says I just want to satisfy my heart about the way you resurrect the dead. So, Abraham is co-operative in this conversation as he says the truth and expresses what is in his heart. In this same verse the maxim of manner is also found which will be explained later. The maxim of quality is also met in the following verse:

(16)

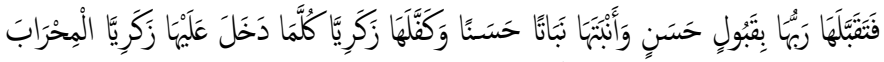

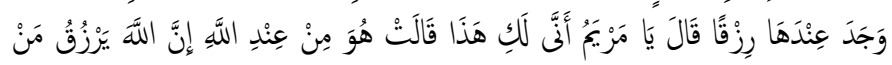

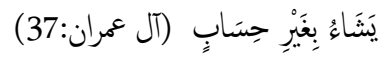

So her Lord accepted her with good acceptance and caused her to grow in a good manner and put her in the care of Zechariah. Every time Zechariah entered upon her in the prayer chamber, he found with her provision (food, fruits, etc.). He said, "O Mary, from where is this [coming] to you?" She said, "It is from Allah. Indeed, Allah provides for whom He wills without account." (37) (Saheeh International, 2004, p. 49)

Here, in (16),Zechariah, truthfully, wants to know the source of Mary's provision and hence she answers him truthfully that it was from Allah. And for adequateness of her knowledge she gives clear attributes to Allah, Indeed, Allah provides for whom He wills without account. In the above two verse we have seen examples of observing the maxim of quality. Now let us consider some cases in which the maxim is disregarded. 
(17)

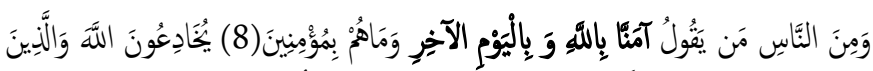

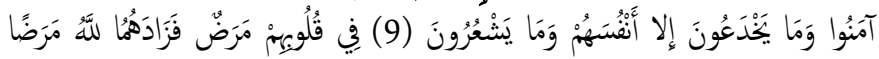

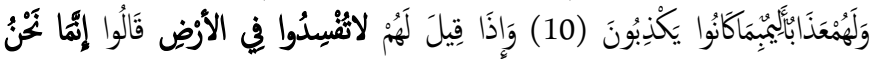

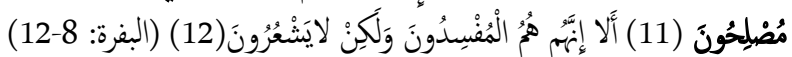

And of the people are some who say, "We believe in Allah and the Last Day," but they are not believers(8)They [think to] deceive Allah and those who believe, but they deceive not except themselves and perceive [it] not (9)In their hearts is disease, so Allah has increased their disease; and for them is a painful punishment because they [habitually]used to lie (10)And when it is said to them, "Do not cause corruption on the earth," they say, "We are but reformers" (11)Unquestionably, it is they who are the corrupters, but they perceive [it] not (12) (Saheeh International, 2004, p. 3)

This example is self-explanatory, i.e. it is a typical example of ignoring the maxim of quality, namely violating the maxim of quality. This verse quotes the speech of the hypocrites when saying that they believe in God and the Last Day but in actuality the do not have such a belief. They do so in the purpose of deceiving God and the true believers, as all the rest of the verses in (17) provide explanations for their being lying in their claims as being true believers or reformers.

Another example of maxim of quality non observance is in (18): (18)

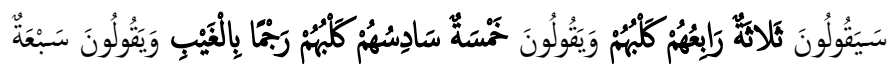

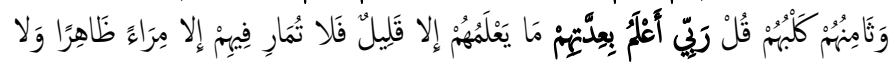

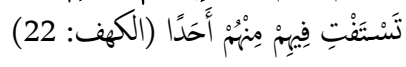

They [i.e., people] will say there were three, the fourth of them being their dog; and they will say there were five, the sixth of them being their dog - guessing at the unseen; and they will say there were seven, and the eighth of them was their dog. Say, [O Muhammad], "My Lord is most knowing of their number. None knows them except a few. So do not argue about them except with an obvious argument and do not inquire about them among [the speculators] from anyone." (Saheeh International, 2004, p. 278)

Here, this verse tells us about those people who, blindly, talk about the number of the people who are known as the companions of the cave, As habulkahf. This can be regarded as against the second submaxim of quality, do not say that for which you lack evidence. One can say that this contains an infringing of the maxim of quality because the speech of those who talk about of number of the companions of the cave is based on imperfect knowledge because they lack enough evidence. As a result their speech will lack quality and authenticity.

A typical example of disregarding the maxim of quality is the use of metaphor. A metaphor is found in:

(19)

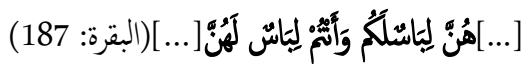

[...] They [Your wives] are clothing for you and you are clothing for them [...] (Saheeh International, 2004, p. 26)
In (19) spouses have been compared to clothes to one another. At the first sight, linguistically, there is no connection between couples and clothes while when you think deeply you find that a wife is the clothing for her husband in the sense she prevents him from committing any immoral behaviours pertained to women and the same holds true for the man being the clothes of the wife. In this metaphor the maxim of quality has been blatantly flouted.

An irony (or sarcasm), which is again an example of flouting the maxim of quality, is displayed here: (20)

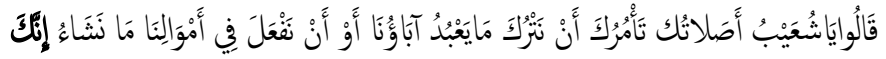

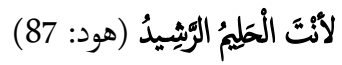

They said, "O Shu'ayb, does your prayer [i.e., religion] command you that we should leave what our fathers worship or not do with our wealth what we please? Indeed, you are the forbearing, the discerning!" (Saheeh International, 2004, p. 210)

In (20), the people of Shu'ayb describe him, ironically, as being forbearing and discerning which are two positive attributes but they used them to mean the opposite.

\section{B. MAXIM OF QUANTITY}

Quran in itself is concise and precise. It is concise in the sense that it talks about crucial and necessary things only. It is precise in the sense that it talks about those necessary and crucial things in a detailed explanation. So it is quantity as whole is perfect. .ii $^{\text {ii }}$ The following are two examples:

(21)

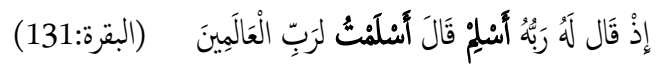

When his Lord said to him [Abraham], "Submit," he said, "I have submitted [in Islam]to the Lord of the worlds." (Saheeh International, 2004, p. 40)

(22)

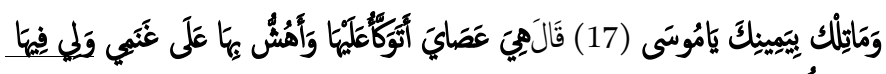

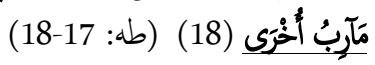

And [Allah asked]what is that in your right hand, O Moses?"(17) $\mathrm{He}$ said, "It is my stuff; I lean upon it, and I bring down leaves for my sheep and I have therein other uses."(18) (Ibid., p. 279)

In both (21) and (22), the maxim of quantity is preserved fully. In (20) Allah orders Abraham to surrender, Abraham immediately replies by saying that he has surrendered to Him. The word 'Aslim' literarily means 'surrender' can implicate surrender to Me alone now but it has not been mentioned by Allah therefore Abraham said 'I have surrendered to the Lord of the worlds.' Furthermore, a very broad sense 'Islam' has been expressed with a single word 'Aslim' which can be again elaborated, but keeping maxim of quantity, it is as informative as is required. So, the conversers are cooperative to each other. In the same token, Moses in (22) responds to the inquiry by Allah in a way that can match the maxim of quantity specification, on the one hand. One can also say that, on the other hand, it can be an example of a clash of the maxims; Moses's speech is keeping quantity but ignoring quality by 
mentioning the underlined clause at the end of his reply to the question.

Example (18), mentioned earlier, can be regarded as an instance of opt out because even God Himself does not provide the exact figure of the companions of the cave. Thus, it can be said that (18), in addition to ignoring the quality maxim, it disregards the quantity as well. Another example of opting out the maxim of quantity is in the issue of the time of the day of resurrection. In Quran, in many times people questioned about it but the answer is that God will not reveal this time and it will remain one of the unseen issues that only He knows:

(23)

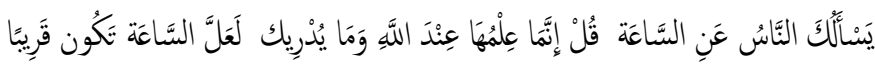

$$
\begin{aligned}
& \text { (الاحزاب: 63) }
\end{aligned}
$$

People ask you concerning the Hour. Say, "Knowledge of it is only with Allah. And what may make you perceive? Perhaps the Hour is near." (Saheeh International, 2004, p. 416)

For another non-observance of quantity, look at the following example:

(24)

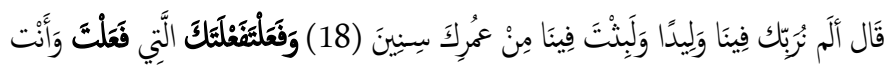

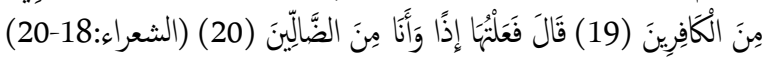

[Pharaoh] said, "Did we not raise you among us as a child, and you remained among us for years of your life? (18) And [then] you did your deed which you did ${ }^{\mathrm{iv}}$, and you were of the ungrateful."(19) [Moses] said, "I did it, then, while I was of those astray [i.e. ignorant]. (Saheeh International, 2004, p. 355)

The items in bold typefaces in the aforementioned verses provide an example of a tautology. Here it is an example of flouting the maxim of quality. The tautology generates an implicature; you did a crime that it was something horrible, and as a result you are criminal, you killed someone from my relatives.

\section{Maxim of Relevance}

Like the other two previous maxims, Quranic conversations contain instances of keeping the maxim of relevance and examples wherein it is disregarded. Look at the following examples:

(25)

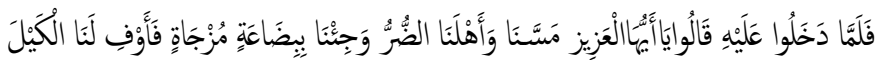

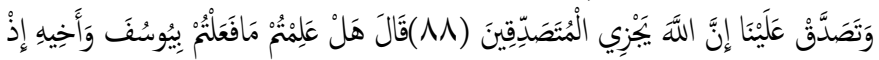

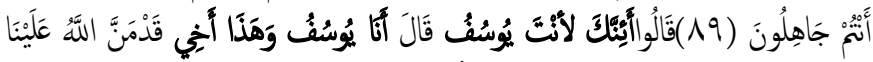

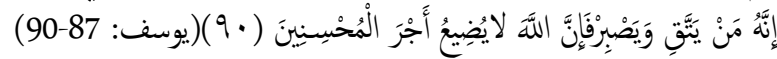

So when they entered upon him [i.e., Joseph], they said, $\underline{\text { OO }}$ "Azeez, adversity has touched us and our family, and we have come with goods poor in quality, but give us full measure and be charitable to us. Indeed, Allah rewards the charitable."(88) He said, "Do you know what you did with Joseph and his brother when you were ignorant?" (89) They said, "Are you indeed Joseph?" He said, "I am Joseph, and this is my brother. Allah has certainly favored us. Indeed, he who fears
Allah and is patient, then indeed, Allah does not allow to be lost the reward of those who do good"(90). (Saheeh International, 2004, pp. 224-5)

As the bold parts in (25) show, the brothers of Joseph ask him the question whether he is, as Azeez, their brother, Joseph; he (Joseph) relevantly replies their question. A thorough investigation tells us that at the very beginning of the conversation Joseph's brothers asked for a favor from the Azeez, not knowing that he was their brother, but Azeez changes the direction of the conversation by providing an irrelevant, as the underlined parts indicate, but crucial, topic to the conversation; that he is Joseph. So this can be regarded as anon-observance of the maxim. Another example of observing the maxim of relevance is the following:

(26)

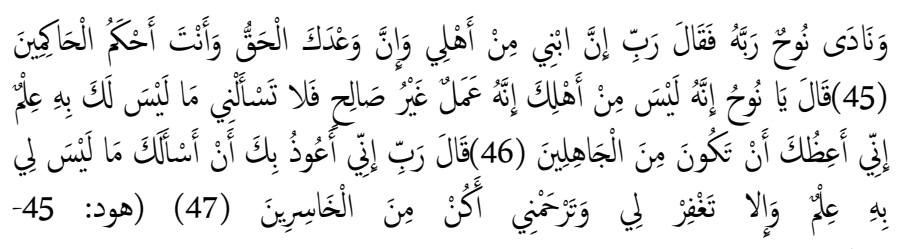

And Noah called to his Lord and said, "My Lord, indeed my son is of my family; and indeed, Your promise is true; and You are the most just of judges!" (45)He said, "O Noah, indeed he is not of your family; indeed, he is [one whose] work was other than righteous, so ask Me not for that about which you have no knowledge. Indeed, I advise you, lest you be among the ignorant (46). [Noah] said, "My Lord, I seek refuge in You from asking that of which I have no knowledge. And unless You forgive me and have mercy upon me, I will be among the losers." (47) (Saheeh International, 2004, p. 206)

The aforesaid example, (26), contains an implicature; though at the first sight Noah's speech seems to be mismatching the reply by Allah. This is because Noah's utterance has a declarative form but it is a request, i.e., supplication, in function; he begs Allah to forgive his son, that is why Allah refuses his request and advises him not to ask Him about something that he lacks sufficient knowledge. Thus, one can say that it is fully relevant; as Noah's reply to Allah's words indicates this fact, taking refuge in Allah from asking or requesting for something that he has no knowledge about. The situation of maxim of relevance in (27), again a scene in Yusuf Sura, is totally different:

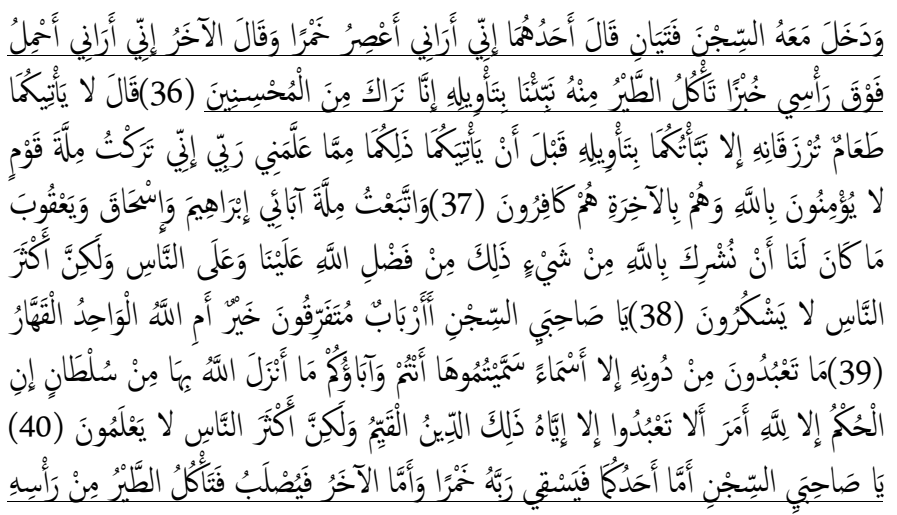




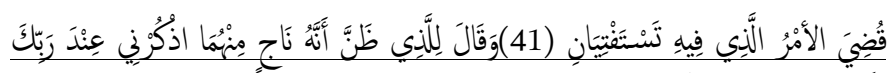

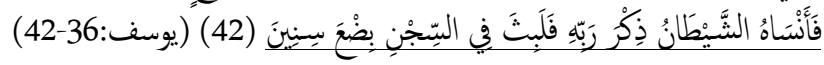

And there entered the prison with him two young men. One of them said, "Indeed, I have seen myself [in a dream] pressing wine." The other said, "Indeed, I have seen myself carrying upon my head [some] bread, from which the birds were eating. Inform us of its interpretation; indeed, we see you to be of those who do good."(36). He said, "You will not receive food that is provided to you except that I will inform you of its interpretation before it comes to you. That is from what my Lord has taught me. Indeed, I have left the religion of a people who do not believe in Allah, and they, in the Hereafter, are disbelievers (37). And I have followed the religion of my fathers, Abraham, Isaac and Jacob. And it was not for us to associate anything with Allah. That is from the favor of Allah upon us and upon the people, but most of the people are not grateful. (38). O [my] two companions of prison, are separate lords better or Allah, the One, the Prevailing? (39) You worship not besides Him except [mere] names you have named them, you and your fathers, for which Allah has sent down no authority. Legislation is not but for Allah. He has commanded that you worship not except Him. That is the correct religion, but most of the people do not know (40). O two companions of prison, as for one of you, he will give drink to his master of wine; but as for the other, he will be crucified, and the birds will eat from his head. The matter has been decreed about which you both inquire" (41). And he said to the one whom he knew would go free, "Mention me before your master." But Satan made him forget the mention [to] his master, and he [i.e., Joseph] remained in prison several years (42). (Saheeh International, 2004, pp. 218-19)

The situation is in (27) is very different, something that Grice does not talk about. When the two prison companions of Joseph ask him for the interpretation of their dreams Joseph suspends his answer. According to the CP, Joseph is not cooperative, namely because he ignores the $\mathrm{CM}$ of relevance, but this is not the case. We can say that it is relevant because if Joseph had answered or better to say interpreted their dreams immediately they might have not believed in him as a dream interpreter and consequently as a prophet of God. And one can say that his suspension made the two prison companions think of what comes next and prepare them for the next phase of their life. After he explains the source of his knowledge and Message of Allah to them, Joseph tells them the interpretation of their dreams. The intended conversation of this scene is apparent in the underlined two verses. Thus, according to the Grice (27) disregards the maxim of relevance and the way of the nonobservance appears to be suspension. This type of suspension is different; it is a temporary one.

\section{MAXIM OF MANNER}

The maxim and submaxims of manner match the conversations and descriptions found in Quran. Example (28) is an illustration in which Allah addresses His speech to all human beings and explains the phases through which $\mathrm{He}$ created them and $\mathrm{He}$ will resurrect them in the hereafter:

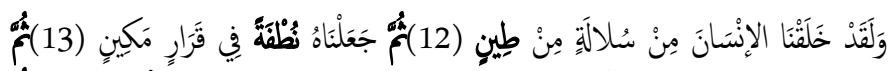

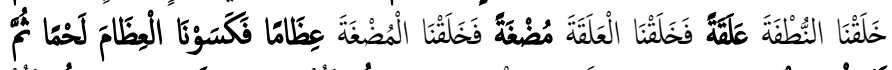

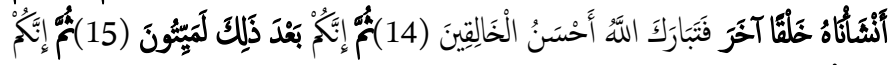

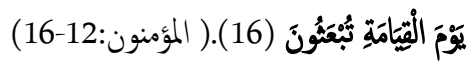

And certainly did We create man from an extract of clay. Then We placed him as a sperm-drop in a firm lodging [i.e., the womb]. Then We made the sperm-drop into a clinging clot, and We made the clot into a lump [of flesh], and We made [from] the lump, bones, and We covered the bones with flesh; then We developed him into another creation. So blessed is Allah, the best of creators 15 . Then indeed, after that you are to die. Then indeed you, on the Day of Resurrection, will be resurrected. (Saheeh International, 2004, p. 372)

The description in (28), particularly the items in bold face, tell us the accurate and well orderly steps of human creation. This is a very lucid and brief visualization of the sophisticated steps of human creation, death, and resurrection. This example is fully in line with Grice's maxim of manner which requires the speaker(s) to be perspicuous which means to be brief, orderly, and avoiding obscurity and ambiguity.

The same can be said concerning the way Allah describes Himself, in (29), via the way He created the humans in way that the criteria of the maxim of manner are observed:

(29)

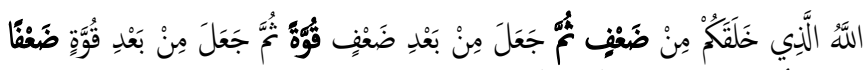

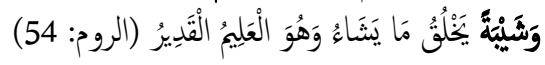

Allah is the One Who created you from weakness, then made after weakness strength, then made after strength weakness and white hair. $\mathrm{He}$ creates what $\mathrm{He}$ wills, and $\mathrm{He}$ is the Knowing, the Competent. (Saheeh International, 2004, p. 398)

In an occasion when Moses's people had a problem, namely one person was killed secretly. A quarrel between two tribes happened; each tribe accused the other. Then they decided to go to Moses to judge between them. As a result the following conversation occurred:

(30)

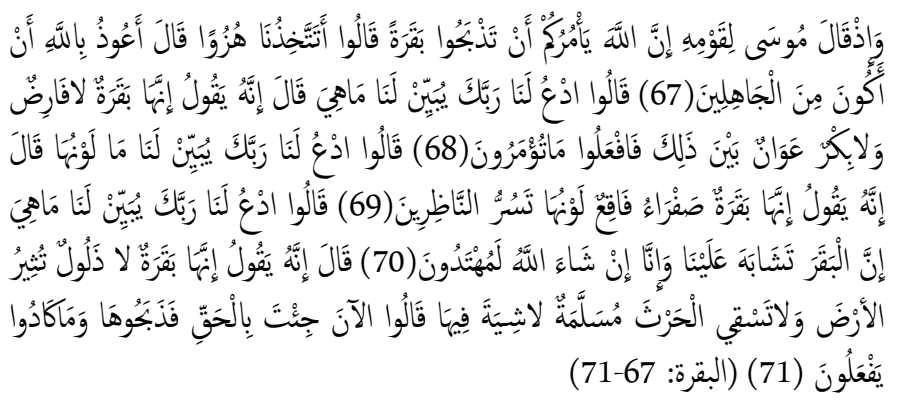

And [recall] when Moses said to his people, "Indeed, Allah commands you to slaughter a cow." They said, "Do you take us in ridicule?" He said, "I seek refuge in Allah from being among the ignorant. "They said, "Call upon your Lord to make clear to us what it is." [Moses] said, "[Allah] says, 'It is a cow which is neither old nor virgin, but median between that,' so do what you are commanded. "They said, "Call upon your Lord to 
show us what is her color." He said, "He says, 'It is a yellow cow, bright in color - pleasing to the observers.' "They said, "Call upon your Lord to make clear to us what it is. Indeed, [all] cows look alike to us. And indeed we, if Allah wills, will be guided. "He said, "He says, 'It is a cow neither trained to plow the earth nor to irrigate the field, one free from fault with no spot upon her.' "They said, "Now you have come with the truth." So they slaughtered her, but they could hardly do it. (Saheeh International, 2004, p. 10)

The dialogue between Moses and his people quoted in (30) can be regarded as an example of disregarding the submaxim of manner, 'be brief' God's command for solving the problem was that they slaughter a cow. So, it was brief and clear but the people refused to do it immediately. On the contrary they asked for further specifications. The more they asked for explanation, the harder the obtainability of the cow would be. Accordingly, one can say that this conversation lacks the 'be brief' submaxim of manner and it can be regarded as result of the rebutting of the people towards the immediate abidance of God's order via Moses.

\section{CONCLUSION}

To conclude, the Quranic conversations and descriptions provide a fruitful source for conducting linguistic pragmatic analyses, in general and Grice's CP and CMs in particular. As we have noticed in the previous section, in the selected conversations quoted from Quran there are observances and non-observances of the $\mathrm{CP}$ and CMs. In most of the cases, the participants are co-operative to each other and they abide by the criteria of CMs. This does not mean that there were not cases in which the CMs criteria were ignored. In some examples we had flouting, opting out, suspension, and even infringement. It is also concluded that infringing of a maxim might be due to imperfect knowledge about the subject matter of the conversation. The suspension found in one of the examples is called a temporal suspension. As shown throughout the quoted Quranic conversations, Grice's CP and CMs, whether observed or not, have proven the authenticity and validity of the model's universality. What is also apparent from this study is that the Quranic conversations exemplify the perfection of the profound language that addresses the humans in a way that they use in their everyday interactions.

\section{REFERENCES}

Al-Qu'ran Al-Kareem (The Holy Qur'an)

Badejani, A. E., M. A. Badejani \& A. R.Lotfi (2013). Meaning in the Holy Quran: A text analysis of the "Surah Livestock" ("Al-An'am") within the framework of Grice's theory of implicature. Retrieved $\begin{array}{ll}\text { on } & \text { from }\end{array}$ www.davidpublishing.com/DownLoad/? id $=14410$

Black, E. (2006). Pragmatic stylistics. Edinburgh: Edinburgh University Press.

Grice, P. (1975). Logic and conversation. In P. Cole \& J. L. Morgan (Eds.), Syntax and semantics (pp. 41-58). New York, NY: Academic Press. Retrieved on 21/3/2016 from http://www.ucl.ac.uk/ls/studypacks/Grice-Logic.pdf

Levinson, S. C. (1983). Pragmatics. Cambridge: Cambridge University Press.

Mahfouz, A. R. (2013).A pragmatic study of the dialogue verses in the glorious Quran. Retrieved on 16/3/2016 from https://www.ljubljuknigi.ru/store/ru/book/a-pragmatic-study-of-thedialogic-verses-in-the-glorious-quran/isbn/978-3-659-48445-2

Saheeh International (2004) The Qur'an: English meanings. Jiddah: AlMuntada Al-Islami

Strazny, Philipp (Editor). (2005). Encyclopaedia of linguistics (Volume 1, A-L). New York: Taylor \& Francis Books, Inc.

The Appendix of Al-Quran Al-Kareem (2014). (4th ed.). Damasks: Dar Ebn Hajar.

Thomas, J. (1995). Meaning in interaction: An introduction to pragmatics. London: Longman.

Younis, N. O. (2015). A pragmatic study of advertisements in English. University of Salahaddin-Hawler: Unpublished (MA thesis).

Yule, G. (1996). Pragmatics. Oxford: Oxford University Press. 